\title{
RISK ASSESSMENT ISSUES IN THE PROCESS OF FREIGHT TRANSPORT PERFORMANCE
}

\section{PROBLEMATYKA OCENY RYZYKA W PROCESIE OBSŁUGI TRANSPORTU LADUNKÓW TOWAROWYCH}

\author{
Agnieszka Tubis, Sylwia Werbińska-Wojciechowska
}

Wroclaw University of Science and Technology, Faculty of Mechanical Engineering Politechnika Wrocławska, Wydział Mechaniczny

\begin{abstract}
In the presented paper, authors focus on the issues related to risk assessment of transport processes performance. Thus, there are presented the basic definitions related to the research area. Later, there is discussed the possibility of risk assessment performance in the freight transport, outlining an assessment approach compatible with ISO 31000 standard and ERM concept. This gives the possibility for the presentation of risk assessment of transport processes performance in the chosen road transport company. The article concludes with a summary, including directions for further research.
\end{abstract}

Keywords: transportation process, risk assessment, ISO 31000

Streszczenie: $W$ artykule autorzy skupili się na zagadnieniach zwiazanych z ocena ryzyka realizowanych procesów transportowych. W zwiazku z tym, przedstawiono podstawowe definicje zwiazane $z$ badana tematyka. Nastęnie, omówiono możliwości oceny ryzyka $w$ transporcie tadunków towarowych, przedstawiając podejście do oceny zgodne z norma ISO 31000 i koncepcja ERM. To pozwolito na przedstawienie przykładu oceny ryzyka realizowanych procesów transportowych w wybranym przedsiębiorstwie transportu drogowego. Artykut kończy podsumowanie oraz wytyczne obejmujace kierunki dalszych badań.

Stowa kluczowe: proces transportowy, ocena ryzyka, ISO 31000 
Risk assessment issues in the process of freight transport performance

Problematyka oceny ryzyka w procesie obstugi transportu ładunków towarowych

\section{RISK ASSESSMENT ISSUES IN THE PROCESS OF FREIGHT TRANSPORT PERFORMANCE}

\section{Introduction}

Changing market conditions and regulations, increasing customer demands and service standards, the development of information technology, but also the growing number of terrorist acts and increasing criminality made that the concept of risk management in business operations is becoming increasingly popular. Taking into account the transport service companies, it can be said that they bear relatively high risk costs compared to other business activities [7]. It is therefore extremely important that the companies, involved in the transport process performance, identify as many hazards as possible (random and non-hazardous) as well as identify the places in the transport chain most vulnerable to disruptions [23]. This is the only possible way to try to reduce the consequences or eliminate factors that generate a risk of hazardous event occurrence. Meanwhile, traditional risk assessment models are primarily aimed at measuring the safety of transport operations and lacking a holistic approach recommended, among others by the ISO 31000 standard.

The aim of this paper is to present a new approach to risk assessment in road transport companies and to justify its implementation on the example of the research carried out in the chosen freight transport company. At the same time, the starting point for identifying potential hazards is a process approach that takes into account both the transport handling activities and the resources involved. As a result, the next Section presents the basic definitions in the field of transport and the implementation of transport processes. Then the focus is placed on the risk assessment in the freight handling process. This gives the possibility to define the main operational risk groups in a given transport activity. In the next step, there is presented an example of risk assessment for a selected road transport company. The article concludes with the summary and guidelines for further research.

\section{Freight transport process - main definitions}

Currently, a number of research works on transport issues can be found in the literature. The development of modern transport technologies, the increase of the importance of intelligent transport systems, the idea of sustainable transport development, and the problems connected with the realization of transport activities (e.g. external transport costs) have increased interest in such concepts as flexibility, productivity, quality, vulnerability and resilience, or reliability of transport processes [24]. At the same time, there are many definitions of transport, transport system or transport process in the available literature.

In the most general sense of transport is an activity whose aim is to overcome space. 
According to the Polish standard [17], transport is a group of operations involving the movement of unit loads, involving both the relocation from place to place and any actions that may be necessary for this purpose, cargo operations (loading, unloading or transhipment), and manipulation process. The essence of transport activities is the implementation of transport processes.

According to PN-EN ISO 9000: 2006 [15], the process is defined as a set of interrelated or mutually interacting actions that transform the inputs into outputs. Nowosielski in their work [13] extends this definition, taking into account, among others, the relationship between input and output of the process, its structure, and principles for the formulation of its targets. As a result, he proposes a definition, in which the process is a structured set of actions, rules of conduct and recommendations, the application of which in practice transforms input states into output states in order to achieve measurable results of significant value from the client's point of view. On the other hand, Piatkowski in his work [14] assumes that the process is oriented chain (string) of events following each other in time and constituting stages, phases, stages of development or transformation leading to a final stage.

Based on the presented process approach, the transport process can be defined as a series of complex organizational, operational and trade sale activities aimed at moving cargo or people from one or several starting points, called points of origin to one or more endpoints, known as delivery points with the use of appropriate means of transport [20]. In contrast, in the work [10], the authors propose a logistic approach, identifying the transport process as a set of activities (operations) that are interrelated in specific relationships and aimed at providing the customer with a certain added value that is understood as elimination or reduction of spatial location discordance in accordance with the standards of the 7R rule. This view of the transport process is consistent with the approach proposed, among others, in [11]. Another approach is presented in the paper [8], where the author defined a transport process as a process that describes the relationship between the states of a transport system over time, and the transport process performance is defined as the course of changes of transport system states over a given time period. On the other hand, according to the Polish standard [17], the transport process is a series of related transport operations carried out consecutively in a fixed order on a particular route and at a certain time.

Based on the definitions presented by the authors of works [13, 18, 25], the transport process can be broadly defined as a set of activities carried out by specialized personnel in strict sequence, associated with the movement of people and goods materials in specific relationships and by appropriate means of transport. At the same time a set of activities includes:

- organizational activities - related to e.g. organization of the transport process performance, or route planning,

- operational - related to the implementation of the transport process, and

- administrative - related e.g. with the preparation of transport documentation. 
Risk assessment issues in the process of freight transport performance Problematyka oceny ryzyka w procesie obstugi transportu ładunków towarowych

Based on the process approach, in such a defined transport process, the input elements are people (administrative staff, supporting staff, and drivers), means of transport, used transport and logistics infrastructure, and other (e.g. the methods, rules, principles, or cost structure). At the output of the transport process can be determined primarily realized transport service of a certain income. The characteristics of the transport process is shown in the Figure 1.

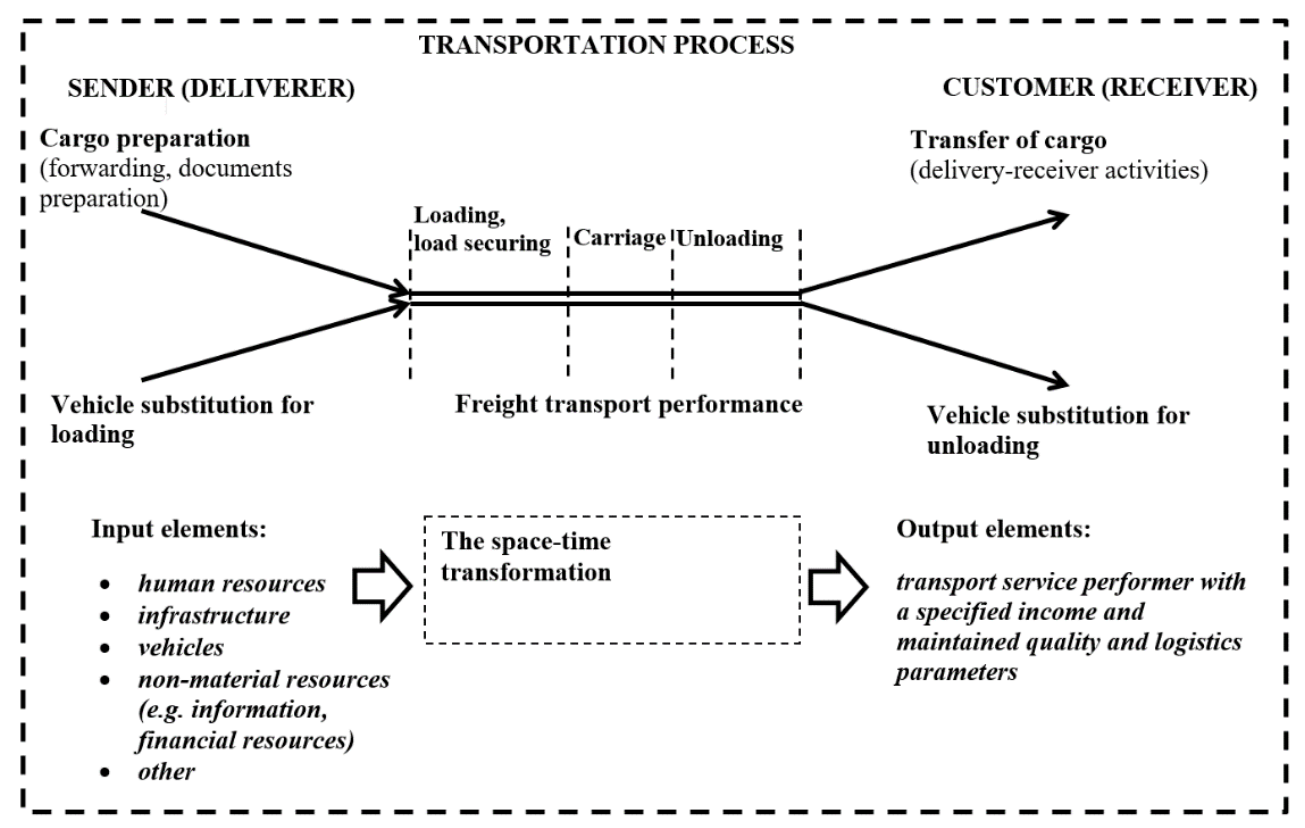

Fig. 1 Characteristics of transportation process Own contribution based on [12, 17, 24]

\section{Risk assessment in freight transport process performance}

Carried out by the authors analysis of publications from the EBSCO database published in the years 2006-2016 and devoted to risk management indicates that research in this area focused overwhelmingly on the five thematic areas: (1) the risk of accidents in transport (e.g. $[9,21]$ ); (2) the risk of the transport of hazardous materials (e.g. [4, 6]); (3) the risk of terrorist threats (e.g. [1, 12]); (4) the risk of damage to transport infrastructure (e.g. [19,22]); (5) the risk of untimely transport performance (e.g. $[3,5])$. It should be noted, that most of the presented research relates primarily to the issue of transport safety. For this reason, risk assessments focus primarily on the events that threaten the safety of cargo, people and the environment. Meanwhile, the risk assessment in transport, in accordance with the ISO 31000 standard, should have a holistic approach. For this purpose, it is necessary to adopt a process approach in the performed analyses.

At the same time, according to the standard [16], risk assessment is defined as the overall process of risk identification, risk analysis and risk evaluation. 
The risk is considered to be the effect of uncertainty on objectives [16]. Overview of the basic definition of the concept of risk can be found, among others, in [2]. According to the author of the work, the proposed definitions generally refer the level of uncertainty to the probability of an adverse event and its consequences. Based on such a defined approach, when conducting the risk assessment analysis, it is important to remember that this is a complex process that requires the involvement of a variety of resources - material, intangible, financial and personal ones. Each of these resources is a potential source of adverse events. So nowadays, it is not possible to limit the performed research efforts to the issues relating to infrastructure, transport participants and possible terrorist acts. At the same time, the transport process is carried out in a specific environment, governed by the law regulations, economic, political and social situations. No less important are therefore the issues of finance, management methods, organizational culture, social norms, communications, legal and political issues, and others. All of these factors should in fact be taken into account by managers, who make decisions about the organization of transport.

Therefore, it is proposed to prepare a new risk assessment model for transport companies. This model currently distinguishes seven risk groups (Figure 2). However, it does not prohibit its further development according to the progress of research and identification of new risk factors associated with transport activities performance.

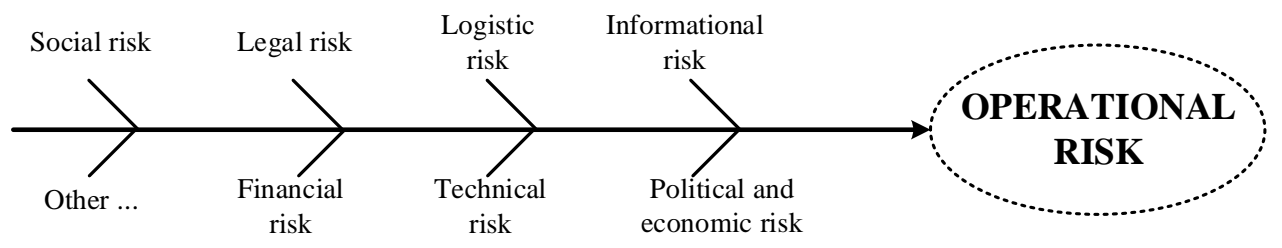

Fig. 2 The proposed model for risk grouping

\section{Case study}

The surveyed company provides transport and forwarding services, mainly in road transport. It currently has 70 own vehicles, which are used primarily to serve customers at regular transport lines. At the same time it cooperates regularly with selected smaller carriers, who have signed contracts with him. The carriers are outsourced to other regular services (those transport services that cannot be served with company's own transport potential) and first appearing additional transport orders. In the absence of the possibility of executing additional orders by the permanent partners, such services are outsourced to other carriers normally acquired through the commodity exchange.

As part of the research in the company, there was conducted the identification and assessment of risk factors associated with the transport and shipping activities. Conducted studies were focused on the assessment of the negative events that threaten the proper implementation of the process of handling the freight transport and the effects of their occurrence. 
Risk assessment issues in the process of freight transport performance Problematyka oceny ryzyka w procesie obstugi transportu ładunków towarowych

Under the concept of correct implementation of the above mentioned process, it is understood as a service performed according to the accepted logistic, qualitative and financial parameters.

As a result of the conducted analyses, it was stated that the threats defined in the five dominant groups described in the literature have in most cases low probability of occurrence for the investigated company business activity. The assessment of these risk groups in the surveyed carrier is shown in Table 1.

Table 1. Characteristics of unwanted events (hazards) occurring in the audited company and defined according to the classical models of risk assessment

\begin{tabular}{|l|l|}
\hline \multicolumn{1}{|c|}{ Group of risk } & \multicolumn{1}{c|}{ Event characteristic } \\
\hline $\begin{array}{l}\text { Accidents in } \\
\text { transport }\end{array}$ & $\begin{array}{l}\text { The event takes place 1-2 times a year, usually involving minor } \\
\text { transport collision, which allow the carriage to continue its } \\
\text { delivery process, in the last 10 years only one road crash has } \\
\text { occurred which prevented further service performance }\end{array}$ \\
\hline $\begin{array}{l}\text { Hazardous material } \\
\text { transport }\end{array}$ & $\begin{array}{l}\text { Hazardous materials are about 10\% of cargo carried. The } \\
\text { company has never reported negative events associated with the } \\
\text { damage of hazardous materials, theft or participation in an } \\
\text { accident with dangerous substances. }\end{array}$ \\
\hline $\begin{array}{l}\text { Transport } \\
\text { infrastructure } \\
\text { failure/damage }\end{array}$ & $\begin{array}{l}\text { Sudden damage to public infrastructure occasionally prevents } \\
\text { proper service delivery. The carrier usually has information } \\
\text { about repairs and detours in advance, so it is included in the } \\
\text { planned route and time of carriage. The high probability of } \\
\text { damage occurs only in the case of own vehicles using by the } \\
\text { carrier. Due to the high electronic complexity of the used } \\
\text { modern transport fleet, any failure is required to be repaired by } \\
\text { service points. These repairs mean turning off the vehicle for } \\
\text { a few hours and sometimes even for a few days. As a result, } \\
\text { even in the case of minor breakdowns, proper transport services } \\
\text { are at risk. }\end{array}$ \\
\hline $\begin{array}{l}\text { Terrorist } \\
\text { threat }\end{array}$ & $\begin{array}{l}\text { None of the drivers engaged in transport operations for the } \\
\text { company, did not participate in the events connected with } \\
\text { terrorist activities. }\end{array}$ \\
\hline $\begin{array}{l}\text { Dhe probability of this event increases in the cases, where the } \\
\text { transport carriers involved are not review, and not cooperated } \\
\text { previously with the company. For this reason, regular } \\
\text { customers and regular orders are served in the first instance by } \\
\text { the own fleet and the carriers, with which the company has } \\
\text { a signed contract. Unchecked carriers obtained for example } \\
\text { through stock exchanges are only used for new, disposable and } \\
\text { minor orders. }\end{array}$ \\
\hline
\end{tabular}

Further process analysis indicated that a significantly higher likelihood was attributed to the occurrence of other events accompanying the operating activities of the transport and forwarding company (Table 2). These events threaten the proper implementation of the process of handling the transport of cargo, and their effects result in negative consequences for the business performance. Assignment of a particular hazard to particular risk groups was carried out on the basis of the qualifying procedure of a given event and not the effects that were incurred. 
Agnieszka Tubis, Sylwia Werbińska-Wojciechowska

Table 2. Hazard events with the highest probability of occurrence in the analysed company

\begin{tabular}{|l|c|}
\hline \multicolumn{1}{|c|}{ A threat to the process performance } & Group of risk \\
\hline $\begin{array}{l}\text { Lack of qualified drivers for the transport activities } \\
\text { performance }\end{array}$ & Social risk \\
\hline $\begin{array}{l}\text { Changes in legislation on minimum wages for drivers } \\
\text { comply with the requirements of selected EU countries } \\
\text { (Germany, France) }\end{array}$ & Legal risk \\
\hline $\begin{array}{l}\text { Improper performance of transport process by the carrier } \\
\text { that is not a permanent business partner }\end{array}$ & Logistic risk \\
\hline $\begin{array}{l}\text { No current information on the effectiveness of the } \\
\text { performed actions }\end{array}$ & Informational risk \\
\hline No current information about the quality of a delivery & Informational risk \\
\hline The increase in fuel prices & Financial risk \\
\hline Invasion of immigrants to vehicles performing transport & Social risk \\
\hline
\end{tabular}

Presented examples of the risks associated with current forward and shipping activities are those that currently have the highest probability of occurrence and whose effects are currently the most cumbersome for managers. They do not include the results of a complete risk analysis carried out in an enterprise and do not exhaust the scope for risk grouping proposed in the new assessment model. They have the task only to show that the classical models of risk assessment in the transport sector do not correspond to the current expectations of the managerial staff. They do not take into account the current information needs accompanying the decision-making processes related to operating activities. At the same time, the strong focus of classical risk assessment models is primarily on security aspects, limiting their adaptability to changing business conditions and the wider environment.

\section{Summary}

Polish transport companies are currently operating under very difficult business conditions. The current "customer market" and "driver market", the changes in the law in the European Union and, above all, the ever-increasing competition, make the learning organizations in this sector are still looking for new solutions improving their existing operations.

One of the future directions of development is the implementation of the risk management concept which, in the case of the TSL sector, plays a very important role and can significantly support the decision-making processes of the managerial staff. It is necessary, however, to develop a traditional approach that takes into account safety, as well as other aspects accompanying the carrier's operating activities.

The model presented in this article is an attempt of a holistic view on the risk assessment of road transport companies. The preliminary research in a selected company confirm the validity of this approach. Therefore, this model will be further developed on the basis of extended studies also performed in other road carriers. 
Risk assessment issues in the process of freight transport performance

Problematyka oceny ryzyka w procesie obstugi transportu ładunków towarowych

\section{References}

[1] Abkowitz M.D.: Transportation risk management: a new paradigm, Submitted for consideration for presentation at the Annual Meeting of the Transportation Research Board and for publication in Transportation Research Record, 2002.

[2] Aven T.: Risk assessment and risk management: review of recent advances on their foundation, European Journal of Operational Research, 2016, 253, $1-13$.

[3] Avineri E., Prashker J. N.: The impact of travel time information on travelers' learning under uncertainty, Transportation, 2006, 33, 393-408.

[4] Bubbico R., Di Cave S., Mazzarotta B.: Preliminary risk analysis for LNG tankers approaching a maritime terminal, Journal of Loss Prevention in the Process Industries, 2009, 22, 634-638.

[5] de Lapparent, M.: Attitude towards risk of time loss in travel activity and air route choices, Journal of Intelligent Transportation Systems: Technology, Planning, and Operations, 2010, 14, 166-178.

[6] Glickman T.S., Erkut E., Zschocke M.S.: The cost and risk impacts of rerouting railroad shipments of hazardous materials, Accident Analysis and Prevention, 2007, 39, 1015-1025.

[7] Haber E.: Trzeci rok kampanii „Rzetelny przewoźnik”, TSL biznes, nr 2/2013.

[8] Jacyna M.: Wybrane zagadnienia modelowania systemów transportowych, Wyd. Politechniki Warszawskiej, Warszawa, 2009.

[9] Jamroz K.: Highway Engineering Risk Assessment, Archives of Transport, 2007, 19, (1-2), $67-74$.

[10] Kisperska-Moroń D., Krzyżaniak S. (red.): Logistyka, ILiM, Biblioteka Logistyka, Poznań, 2009.

[11] Kubicki J., Kuriata A.: Problemy logistyczne w modelowaniu systemów transportowych, WKŁ, Warszawa, 2000.

[12] Milazzo M.F., Ancione G., Lisi R., Vianello Ch., Maschio G.: Risk management of terrorist attacks in the transport of hazardous materials using dynamic geoevents, Journal of Loss Prevention in the Process Industries, 2009, 22, 625-633.

[13] Nowosielski S.: Zarządzanie procesami, dostępne na: procesy.ue.wroc.pl/uploads/pliki/procesy/wyklady/ZPRnowosielskiWYKLAD.pd f (dostęp: 15.11.2016r.).

[14] Piątkowski T.: Analiza i modelowanie procesu sortowania strumienia małogabarytowych ładunków jednostkowych, Rozprawa nr 139, Uniwersytet Technologiczno-Przyrodniczy im. Jana i Jędrzeja Śniadeckich w Bydgoszczy, Bydgoszcz, 2010.

[15] PN-EN ISO 9000:2006: Systemy zarządzania jakością - podstawy i terminologia, PKN, Warszawa, 2006. 
[16] PN-ISO 31000:2010: Zarządzanie ryzykiem - techniki oceny ryzyka, PKN, Warszawa, 2010.

[17] PN-72/M-78000: Transport - określenia podstawowe i podział, Polski Komitet Normalizacji i Miar, Warszawa, 1972.

[18] Pyza D.: Wybrane aspekty modelowania obsługi transportowej w podsystemach dystrybucji, Prace Naukowe Politechniki Warszawskiej, z. 70. Transport, 2009, 139-149.

[19] Salling K.B.: A New Approach to Feasibility Risk Assessment within Transport Infrastructure Appraisal, Procedia - Social and Behavioral Sciences, 2013, 74, 468 $-477$.

[20] Stajniak M., Foltyński M., Hajdul M., Krupa A.: Transport i spedycja. Podręcznik do kształcenia w zawodzie technik logistyk. ILiM, Biblioteka Logistyka, Poznań, 2007.

[21] Stephan K., Kelly M., Mcclure R. , Seubsman S. , Yiengprugsawan V., Bain Ch., Sleigh A.: The Thai Cohort Study Team Distribution of transport injury and related risk behaviours in a large national cohort of Thai adults, Accident Analysis and Prevention, 2011, 43,1062-1067.

[22] Su D., Guo Z., Li Z., Zhou Y.: Operation risk model and monitoring-warning system of expressway tunnels, Transportation Research Procedia, 2016, 14, 1315 $-1324$.

[23] Szczepański M.: Ubezpieczenia w logistyce, Wydawnictwo Politechniki Poznańskiej, Poznań, 2011.

[24] Tubis A., Werbińska-Wojciechowska S.: Issues on vulnerability of passenger transportation system, Journal of KONBiN, 2016, nr. 1, 183-192.

[25] Twaróg J.: Logistyczne wskaźniki oceny transport $\mathrm{w}$ przedsiębiorstwie produkcyjnym, Logistyka, nr 2/2004, 27-30.

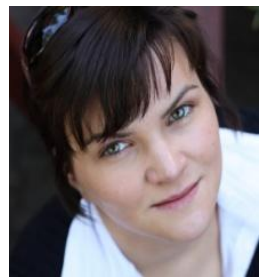

Ph.D. Agnieszka Tubis, Wroclaw University of Technology, Faculty of Mechanical Engineering, Department of Maintenance and Operation of Logistic, Transportation and Hydraulic Systems. PhD Dissertation concerned the cooperation of manufacturers and retailers in the area of planning, forecasting and replenishment according to the concept of CPFR. Current interests are connected with the concept of process controlling being implemented in the maintenance and operations management of vehicles, risk management in transport companies, and she is interests in systems that support decision-making processes of managers in the road transport companies (Share 50\%).

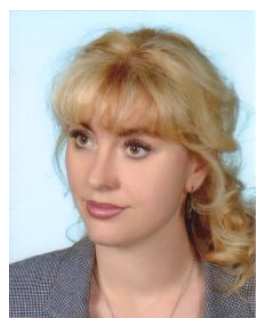

Ph.D. Eng. Sylwia Werbińska-Wojciechowska, Wroclaw University of Technology, Faculty of Mechanical Engineering, Department of Maintenance and Operation of Logistic, Transportation and Hydraulic Systems; PhD Dissertation investigated the modelling issues of logistics systems that support technical systems maintenance and operation processes; current interests are related to the issues of technical systems maintenance modelling with the use of time-delay concept, modeling and performance measurement of transport systems operation, and supply chains resilience and vulnerability problems (Share 50\%). 
Risk assessment issues in the process of freight transport performance

Problematyka oceny ryzyka w procesie obstugi transportu ładunków towarowych

\section{PROBLEMATYKA OCENY RYZYKA W PROCESIE OBSŁUGI TRANSPORTU LADUNKÓW TOWAROWYCH}

\section{Wstęp}

Zmieniające się warunki rynkowe i regulacje prawne, wzrastające wymagania klientów oraz standardy obsługi, rozwój technologii informatycznych, ale również coraz liczniejsze akty terrorystyczne i wzrastająca przestępczość sprawiają, że coraz większym zainteresowaniem cieszą się koncepcje zarządzania ryzykiem w działalności operacyjnej przedsiębiorstw. Patrząc przez pryzmat przedsiębiorstw realizujących usługi transportowe można stwierdzić, iż ponoszą one stosunkowo najwyższe koszty ryzyka w porównaniu do innych działalności gospodarczych [7]. Niebywale istotne jest więc, aby przedsiębiorstwa zaangażowane $\mathrm{w}$ proces transportu zidentyfikowały jak największą liczbę zagrożeń (o charakterze losowym i nielosowym), jak również poznały miejsca w łańcuchu transportowym najbardziej narażone na wystąpienie ryzyka [23]. Tylko w ten sposób bowiem możliwe jest podejmowanie prób ograniczania skutków lub eliminowania czynników generujących występujące ryzyko zakłóceń. Tymczasem tradycyjne modele oceny ryzyka ukierunkowane są przede wszystkim na pomiar bezpieczeństwa realizacji przewozu i brakuje im holistycznego podejścia zalecanego m.in. przez normę ISO 31000.

Celem artykułu jest prezentacja nowego podejścia do oceny ryzyka w przedsiębiorstwach transportu drogowego i uzasadnienie jego implementacji na przykładzie badań przeprowadzonych $\mathrm{w}$ wybranym przedsiębiorstwie transportu towarowego. Punktem wyjścia dla identyfikacji potencjalnych zagrożeń jest przy tym podejście procesowe, które uwzględnia zarówno działania realizowane w obsłudze transportowej ładunków, jak i zaangażowane zasoby. W związku $\mathrm{z}$ tym, w kolejnym punkcie przedstawiono podstawowe definicje $\mathrm{z}$ obszaru transportu oraz realizacji procesów transportowych. Następnie skupiono się na zagadnieniach oceny ryzyka $\mathrm{w}$ procesie obsługi transportowej ładunków. Pozwoliło to na zdefiniowanie podstawowych grup ryzyka operacyjnego występującego $\mathrm{w}$ danej działalności transportowej. W kolejnym kroku przedstawiono przykład oceny ryzyka dla wybranego przedsiębiorstwa transportu drogowego. Artykuł kończy podsumowanie oraz wytyczne obejmujące kierunki dalszych badań.

\section{Proces obsługi transportowej ladunków towarowych - podstawowe definicje}

Obecnie w literaturze można znaleźć szereg prac obejmujących problematykę transportu. Rozwój nowoczesnych technologii transportu, wzrost znaczenia inteligentnych systemów transportowych, idea zrównoważonego rozwoju transportu, czy problemy związane $\mathrm{z}$ realizacją działalności transportowej (np. koszty zewnętrzne transportu) powodują, że wzrasta zainteresowanie takimi koncepcjami jak elastyczność, produktywność, jakość, podatność i odporność na zagrożenia, czy niezawodność realizowanych procesów transportowych [24]. 
Jednocześnie, istnieje wiele definicji pojęcia transport, system transportowy, czy proces transportowy w dostępnej literaturze.

W najogólniejszym znaczeniu transport to działalność, której celem jest pokonywanie przestrzeni. Zgodnie z polską normą [17] transport jest zespołem czynności zwiąanych z przemieszczaniem ładunków jednostkowych, obejmujacym zarówno samo przemieszczanie z miejsca na miejsce, jak $i$ wszelkie dziatania, jakie do tego celu moga być konieczne, czynności ładunkowe (załadunek, wyładunek względnie przeładunek) oraz czynności manipulacyjne. Istotą działalności transportowej jest realizacja procesów transportowych.

Zgodnie z normą PN-EN ISO 9000:2006 [15] proces jest określany jako zbiór dziatań wzajemnie powiazanych lub wzajemnie oddziałujących, które przeksztatcaja wejścia $w$ wyjścia. Nowosielski w swojej pracy [13] rozwinął tą definicję, uwzględniając m.in. relacje między wejściem a wyjściem procesu, strukturę procesu, czy zasady formułowania celów. W rezultacie, zaproponował definicję, w której proces to uporzadkowany zbiór działań, zasad postępowania $i$ zaleceń, których stosowanie $w$ praktyce przekształca stany wejściowe $w$ stany wyjściowe w celu osiagnięcia mierzalnego rezultatu stanowiacego istotna wartość $z$ punktu widzenia klienta. Z kolei Piątkowski w swojej pracy [14] przyjął, że proces jest ukierunkowanym tańcuchem (ciagiem) zdarzeń następujących po sobie $w$ czasie $i$ stanowiacych stadia, fazy, etapy rozwoju lub przeobrażeń prowadzacych do pewnego stadium końcowego.

W oparciu o przedstawione podejście procesowe, proces transportowy może być definiowany jako szereg złożonych czynności organizacyjnych, wykonawczych oraz handlowych, mających na celu przemieszczenie ładunków lub ludzi z jednego lub kilku punktów początkowych, zwanymi punktami nadania do jednego lub kilku punktów końcowych, zwanych punktami odbioru za pomoca odpowiednich środków transportu [20]. Natomiast w pracy [10] autorzy zaproponowali podejście logistyczne, określając proces transportowy jako zbiór dziatań (operacji) pozostajacych między soba $w$ określonych zwiazkach $i$ zmierzających do dostarczenia klientowi określonej wartości dodanej, która rozumiana jest jako eliminacja lub redukcja przestrzennej niezgodności lokalizacyjnej zgodnie ze standardami reguły $7 \mathrm{~W}$. Takie spojrzenie na proces transportowy jest zgodne $\mathrm{z}$ podejściem proponowanym m.in. $\mathrm{W}$ pracy [11]. Inne podejście przedstawiono w pracy [8], gdzie autor procesem transportowym nazwał taki proces, którego opis ma postać związków między stanami systemu transportowego $w$ czasie, a realizacją procesu transportowego określono przebieg zmian stanów systemu transportowego w określonym przedziale czasu.

Natomiast zgodnie z polską normą [17], proces transportowy to szereg zwiazanych $z$ soba operacji transportowych, wykonywanych kolejno $w$ ustalonym porządku na określonej trasie i w określonym czasie. 
Risk assessment issues in the process of freight transport performance Problematyka oceny ryzyka w procesie obstugi transportu ładunków towarowych

$\mathrm{W}$ oparciu o przedstawione definicje, zgodnie z autorami m.in. prac [13, 18, 25], proces transportowy można ogólnie określić jako zespót czynności realizowanych przez wyspecjalizowanych pracowników w ściśle określonej kolejności, zwiazanych z przemieszczaniem osób i dóbr materiałowych $w$ ściśle określonych relacjach oraz za pomoca odpowiednich środków transportowych. Jednocześnie zespół czynności obejmuje:

- działania organizacyjne - związane m.in. $z$ organizacją procesu transportowego, planowaniem tras;

- wykonawcze - związane z realizacją procesu przewozowego, oraz

- administracyjne - związane m.in. $\mathrm{z}$ przygotowaniem dokumentacji transportowej.

W oparciu o podejście procesowe, w tak zdefiniowanym procesie transportowym, elementami na wejściu są ludzie (pracownicy administracyjni, pracownicy pomocniczy, kierowcy), środki transportowe, wykorzystywana infrastruktura transportowo-logistyczna, oraz inne (np. metody, regulaminy, zasady, czy struktura kosztowa). Na wyjściu procesu transportowego przede wszystkim można określić zrealizowaną usługę transportową o określonym przychodzie. Charakterystyka procesu transportowego została przedstawiona na rysunku 1.

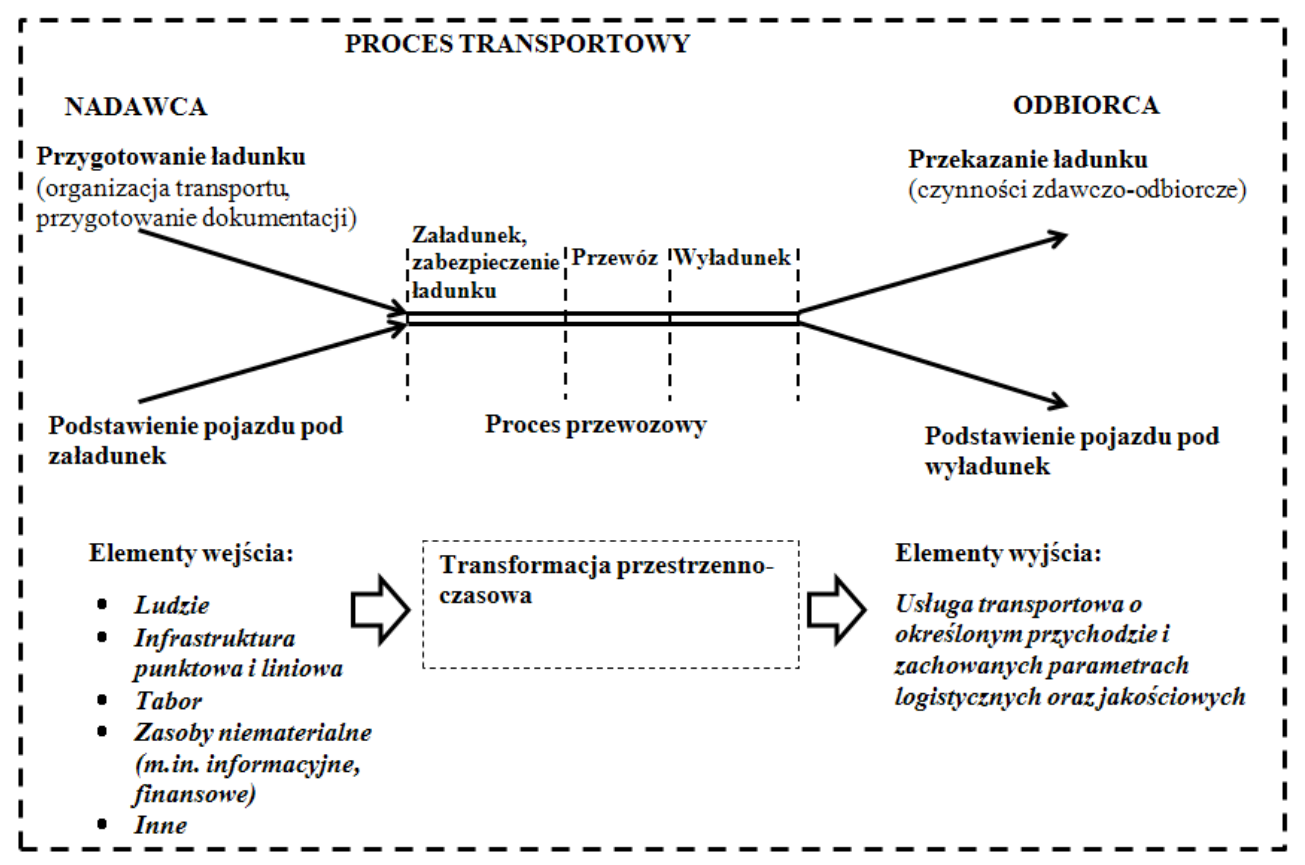

Rys.1 Charakterystyka procesu transportowego

Opracowanie wtasne na podstawie [12, 17, 24] 


\section{Risk assessment in freight transport process performance}

Przeprowadzona przez autorów analiza publikacji z bazy EBSCO z lat 2006-2016 poświęconych zarządzaniu ryzykiem wskazuje, że badania w tym obszarze koncentrują się $\mathrm{w}$ przeważającej większości na 5 obszarach tematycznych: (1) ryzyko wypadków w transporcie (m.in. [9, 21]); (2) ryzyko przewozu materiałów niebezpiecznych (m.in. [4, 6]); (3) ryzyko zagrożeń terrorystycznych (m.in. [1, 12]); (4) ryzyko uszkodzenia infrastruktury transportowej (m.in. $[19,22]) ;(5)$ ryzyko nieterminowości przewozu (m.in. [3, 5]). Zauważyć przy tym należy, iż większość prezentowanych badań odnosi się przede wszystkim do kwestii bezpieczeństwa przewozu. $Z$ tego też powodu przeprowadzane oceny ryzyka koncentrują się przede wszystkim na zdarzeniach zagrażających bezpieczeństwu ładunku, ludzi i środowiska. Tymczasem ocena ryzyka w transporcie, zgodnie z normą ISO 31000 powinna mieć holistyczne podejście. W tym celu konieczne jest jednak przyjęcie podejścia procesowego w przeprowadzanych analizach.

Jednocześnie, zgodnie z daną normą [16], ocena ryzyka jest definiowana jako całościowy proces identyfikacji ryzyka, analizy ryzyka oraz ewaluacji ryzyka. Przy czym za ryzyko uważany jest wpływ niepewności na cele [16]. Przegląd podstawowych definicji pojęcia ryzyka można znaleźć m.in. w pracy [2]. Zgodnie $\mathrm{z}$ autorem danej pracy, proponowane definicje przeważnie odnoszą poziom niepewności do prawdopodobieństwa wystąpienia zdarzenia niepożądanego oraz jego konsekwencji. W oparciu o tak określone podejście, przeprowadzając ocenę ryzyka należy pamiętać, iż jest to złożony proces, do którego realizacji konieczne jest zaangażowanie różnego rodzaju zasobów - materialnych, niematerialnych, finansowych i personalnych. Każdych z tych zasobów jest potencjalnym źródłem wystąpienia zdarzeń niepożądanych. Nie można więc obecnie ograniczać badań jedynie do kwestii odnoszących się do infrastruktury, uczestników procesu transportowego oraz ewentualnych aktów terrorystycznych. Jednocześnie proces transportu realizowanych jest $\mathrm{w}$ określonym otoczeniu, kształtowanym przez obowiązujące przepisy prawne, sytuację gospodarczą, polityczną i społeczną. Nie mniej istotne są $\mathrm{w}$ związku $\mathrm{z}$ tym zagadnienia dotyczące finansów, metod zarządzania, kultury organizacyjnej, norm społecznych, systemów komunikacji, kwestii prawno-politycznych i innych. Wszystkie te czynniki powinny być bowiem brane pod uwagę przez menedżerów podejmujących decyzje dotyczące organizacji transportu.

W związku z powyższym proponuje się przygotowanie nowego modelu oceny ryzyka dla przedsiębiorstw transportowych. Model ten w chwili obecnej wyróżnia siedem grup ryzyka (rys. 2). 
Risk assessment issues in the process of freight transport performance Problematyka oceny ryzyka w procesie obstugi transportu ładunków towarowych

Nie wyklucza się jednak jego dalszej rozbudowy, w miarę postępu prac badawczych i identyfikacji nowych czynników ryzyka, towarzyszących działalności transportowej.

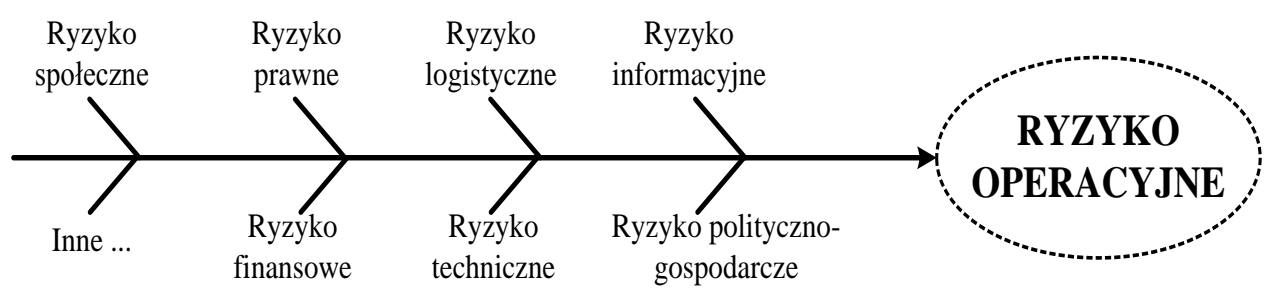

Rys. 2 Proponowany model grupowania ryzyka

\section{Studium przypadku}

Badane przedsiębiorstwo świadczy usługi przewozowo-spedycyjne, głównie w transporcie drogowym. Obecnie posiada 70 pojazdów własnych, wykorzystywanych przede wszystkim do obsługi stałych klientów. Jednocześnie współpracuje regularnie z wybranymi mniejszymi przewoźnikami, którzy mają podpisane $\mathrm{z}$ nim umowy. Tym przewoźnikom zlecane są pozostałe przewozy regularne (tych, dla których nie wystarczył własny potencjał przewozowy) oraz w pierwszej kolejności pojawiające się zlecenia dodatkowe, jednorazowe. W przypadku braku możliwości wykonania pojawiających się zleceń dodatkowych przez stałych kooperantów, przewozy takie zlecane są do innych przewoźników, pozyskiwanych zazwyczaj za pośrednictwem giełdy towarowej.

$\mathrm{W}$ ramach prac badawczych $\mathrm{w}$ przedsiębiorstwie przeprowadzono identyfikację i ocenę czynników ryzyka, towarzyszących prowadzonej działalności transportowo-spedycyjnej. Prowadzone badania ukierunkowane były na ocenę zdarzeń negatywnych zagrażających prawidłowej realizacji procesu obsługi transportowej przewożonych ładunków oraz skutków ich wystąpienia. Pod pojęciem prawidłowej realizacji wyżej wymienionego procesu, rozumie się przy tym usługę wykonaną według przyjętych parametrów logistycznych, jakościowych i finansowych.

W wyniku przeprowadzonych analiz stwierdzono, iż zagrożenia definiowane w ramach pięciu dominujących grup opisywanych $w$ literaturze, $\mathrm{w}$ przedsiębiorstwie mają $\mathrm{w}$ większości przypadków niskie prawdopodobieństwo wystąpienia. Ocenę tych grup ryzyka w badanym przedsiębiorstwie przedstawia tabela 1. 
Tabela 1. Charakterystyka niepożadanych zdarzeń (zagrożeń) występujących $w$ badanej firmie i zdefiniowanych zgodnie z klasycznymi modelami oceny ryzyka.

\begin{tabular}{|c|c|}
\hline Grupa ryzyka & Charakterystyka zdarzenia \\
\hline $\begin{array}{l}\text { Wypadki w } \\
\text { transporcie }\end{array}$ & $\begin{array}{l}\text { Zdarzenie ma miejsce 1-2 razy w roku, zazwyczaj dotyczy } \\
\text { drobnych stłuczek, które pozwalają kontynuować przewóz, } \\
\text { w ostatnich } 10 \text { latach miało miejsce tylko jedno zderzenie } \\
\text { drogowe, które uniemożliwiło dalszą realizację usługi }\end{array}$ \\
\hline $\begin{array}{l}\text { Przewóz } \\
\text { materiałów } \\
\text { niebezpiecznych }\end{array}$ & $\begin{array}{l}\text { Materiały niebezpieczne stanowią około } 10 \% \text { przewożonych } \\
\text { ladunków. W przedsiębiorstwie nie odnotowano nigdy } \\
\text { zdarzeń negatywnych związanych z uszkodzeniem ładunku } \\
\text { niebezpiecznego, kradzieżą lub też uczestnictwem } \\
\text { w wypadku z substancjami niebezpiecznymi. }\end{array}$ \\
\hline $\begin{array}{l}\text { Uszkodzenie } \\
\text { infrastruktury } \\
\text { transportowej }\end{array}$ & $\begin{array}{l}\text { Nagłe uszkodzenia infrastruktury publicznej sporadycznie } \\
\text { uniemożliwiają właściwą realizację usługi. Przewoźnik } \\
\text { z wyprzedzeniem posiada zazwyczaj informacje o remontach } \\
\text { i objazdach, dzięki temu uwzględnia je w planowanej trasie } \\
\text { i czasie przewozu. Wysokie prawdopodobieństwo } \\
\text { uszkodzenia występuje jedynie w przypadku pojazdów } \\
\text { własnych wykorzystywanych przez przewoźnika. Ze } \\
\text { względu na wysoką złożoność elektroniczną, użytkowanej } \\
\text { nowoczesnej floty transportowej, wszelkie uszkodzenia } \\
\text { wymagają naprawy przez punkty serwisowe. Naprawy te } \\
\text { oznaczają zaś wyłączenie pojazdu na kilka godzin, a czasami } \\
\text { nawet na kilka dni. W efekcie, nawet przy drobnych } \\
\text { awariach, zagrożona jest właściwa realizacja usługi } \\
\text { transportowej. }\end{array}$ \\
\hline $\begin{array}{l}\text { Zagrożenie } \\
\text { terrorystyczne }\end{array}$ & $\begin{array}{l}\text { Żaden z kierowców, wykonujących przewozy na rzecz } \\
\text { przedsiębiorstwa, nie uczestniczył w wydarzeniach } \\
\text { związanych z działalnością terrorystyczną. }\end{array}$ \\
\hline $\begin{array}{l}\text { Nieterminowość } \\
\text { przewozu }\end{array}$ & $\begin{array}{l}\text { Prawdopodobieństwo wystąpienia tego zdarzenia wzrasta } \\
\text { w przypadkach, kiedy do przewozów angażowani są } \\
\text { przewoźnicy niesprawdzeni, niewspółpracujący wcześniej } \\
\text { z przedsiębiorstwem. Z tego względu do stałych klientów } \\
\text { i regularnych zleceń w pierwszej kolejności } \\
\text { wykorzystywana jest flota własna i przewoźnicy, z którymi } \\
\text { przedsiębiorstwo ma podpisaną umowę. Z niesprawdzonych } \\
\text { przewoźników pozyskanych np. poprzez giełdy transportowe } \\
\text { korzysta się jedynie w przypadku nowych, jednorazowych } \\
\text { i małoistotnych zleceń. }\end{array}$ \\
\hline
\end{tabular}


Risk assessment issues in the process of freight transport performance Problematyka oceny ryzyka w procesie obstugi transportu ładunków towarowych

Dalsza analiza procesowa wskazała, że zdecydowanie wyższe prawdopodobieństwo przypisane jest do wystąpienia innych zdarzeń towarzyszących działalności operacyjnej przedsiębiorstwa transportowospedycyjnego (tabela 2).

Wydarzenia te zagrażają prawidłowej realizacji procesu obsługi transportowej ładunku, a ich efekty powodują negatywne skutki dla prowadzonej działalności. Przypisanie danego zagrożenia do poszczególnych grup ryzyka zostało przeprowadzone na podstawie postępowania kwalifikującego charakter danego zdarzenia, a nie skutki jakie zostały poniesione.

Tabela 2. Zdarzenia o największym prawdopodobieństwie wystapienia $w$ analizowanej firmie

\begin{tabular}{|l|l|}
\hline Zagrożenie dla realizacji procesu & Grupa ryzyka \\
\hline $\begin{array}{l}\text { Brak wykwalifikowanych kierowców do realizacji } \\
\text { przewozu }\end{array}$ & Ryzyko społeczne \\
\hline $\begin{array}{l}\text { Zmiany w przepisach prawnych dotyczących płacy } \\
\text { minimalnej dla kierowców zgodnych z wymaganiami } \\
\text { wybranych krajów UE (Niemcy, Francja) }\end{array}$ & Ryzyko prawne \\
\hline $\begin{array}{l}\text { Niewłaściwe wykonanie przewozu przez przewoźnika } \\
\text { niebędącego stałym kontrahentem przedsiębiorstwa }\end{array}$ & Ryzyko logistyczne \\
\hline $\begin{array}{l}\text { Brak bieżącej informacji o efektywności } \\
\text { podejmowanych działań }\end{array}$ & Ryzyko informacyjne \\
\hline $\begin{array}{l}\text { Brak aktualnej informacji o jakości zrealizowanej } \\
\text { dostawy }\end{array}$ & Ryzyko informacyjne \\
\hline Wzrost cen paliwa & Ryzyko finansowe \\
\hline $\begin{array}{l}\text { Wtargnięcie imigrantów do pojazdów realizujących } \\
\text { przewóz }\end{array}$ & Ryzyko społeczne \\
\hline
\end{tabular}

Przedstawione przykłady zagrożeń towarzyszących obecnej działalności przewozowo-spedycyjnej, dotyczą tych zdarzeń, które charakteryzują się obecnie najwyższym prawdopodobieństwem wystąpienia i których skutki są obecnie najbardziej uciążliwe dla menedżerów. Nie obejmują one wyników kompletnej analizy ryzyka przeprowadzonej $\mathrm{w}$ przedsiębiorstwie i nie wyczerpują zakresu grupowania ryzyka, zaproponowanego w nowym modelu oceny. Mają ona za zadanie pokazać jedynie, iż klasyczne modele oceny ryzyka dotyczące sektora transportowego nie odpowiadają obecnym oczekiwaniom kadry menedżerskiej. Nie uwzględniają one bowiem aktualnych potrzeb informacyjnych towarzyszących procesom decyzyjnym, odnoszących się do działalności operacyjnej. Jednocześnie silne ukierunkowanie klasycznych modeli oceny ryzyka przede wszystkim na aspekty bezpieczeństwa, ogranicza ich dostosowanie do zmieniających się warunków biznesowych i szeroko rozumianego otoczenia. 


\section{Podsumowanie}

Polskie przedsiębiorstwa transportowe funkcjonują obecnie w bardzo trudnych warunkach biznesowych. Obowiązujący „rynek klienta” oraz „rynek kierowcy”, zmiany $\mathrm{w}$ przepisach prawnych następujące $\mathrm{w}$ państwach Unii Europejskiej, a przede wszystkim stale nasilająca się konkurencja, sprawiają, że organizacje uczące się z tego sektora poszukują wciąż nowych rozwiązań doskonalących ich dotychczasową działalność.

Jednym z kierunków rozwoju jest wdrożenie koncepcji zarządzania ryzykiem, które w przypadku sektora TSL odgrywa wyjątkowo dużą rolę i w istotny sposób może wesprzeć procesy decyzyjne kadry menedżerskiej. Aby to jednak było możliwe konieczne jest rozbudowanie tradycyjnego podejścia, uwzględniającego przede wszystkim bezpieczeństwo, o inne aspekty towarzyszące działalności operacyjnej przewoźnika.

Przedstawiony $\mathrm{w}$ artykule model jest próbą holistycznego spojrzenia na ocenę ryzyka w działalności przedsiębiorstw transportu drogowego. Przedstawione wstępne badania $\mathrm{w}$ wybranym przedsiębiorstwie potwierdzają słuszność takiego podejścia. Z tego też względu model ten będzie dalej rozwijany $\mathrm{w}$ oparciu o poszerzone badania również u innych przewoźników drogowych.

\section{Literatura}

[1] Abkowitz M.D.: Transportation risk management: a new paradigm, Submitted for consideration for presentation at the Annual Meeting of the Transportation Research Board and for publication in Transportation Research Record, 2002.

[2] Aven T.: Risk assessment and risk management: review of recent advances on their foundation, European Journal of Operational Research, 2016, 253, 1-13.

[3] Avineri E., Prashker J. N. : The impact of travel time information on travelers' learning under uncertainty, Transportation, 2006, 33, 393-408.

[4] Bubbico R., Di Cave S., Mazzarotta B.: Preliminary risk analysis for LNG tankers approaching a maritime terminal, Journal of Loss Prevention in the Process Industries, 2009, 22, 634-638.

[5] de Lapparent, M.: Attitude towards risk of time loss in travel activity and air route choices, Journal of Intelligent Transportation Systems: Technology, Planning, and Operations, 2010, 14, 166-178.

[6] Glickman T.S., Erkut E., Zschocke M.S.: The cost and risk impacts of rerouting railroad shipments of hazardous materials, Accident Analysis and Prevention, 2007, 39, 1015-1025. 
Risk assessment issues in the process of freight transport performance Problematyka oceny ryzyka w procesie obstugi transportu ladunków towarowych

[7] Haber E.: Trzeci rok kampanii „Rzetelny przewoźnik”, TSL biznes, nr 2/2013.

[8] Jacyna M.: Wybrane zagadnienia modelowania systemów transportowych, Wyd. Politechniki Warszawskiej, Warszawa, 2009.

[9] Jamroz K.: Highway Engineering Risk Assessment, Archives of Transport, 2007, 19, (1-2), $67-74$.

[10] Kisperska-Moroń D., Krzyżaniak S. (red.): Logistyka, ILiM, Biblioteka Logistyka, Poznań, 2009.

[11] Kubicki J., Kuriata A.: Problemy logistyczne w modelowaniu systemów transportowych, WKŁ, Warszawa, 2000.

[12]Milazzo M.F., Ancione G., Lisi R., Vianello Ch., Maschio G.: Risk management of terrorist attacks in the transport of hazardous materials using dynamic geoevents, Journal of Loss Prevention in the Process Industries, 2009, 22, 625-633.

[13] Nowosielski S.: Zarządzanie procesami, dostępne na: procesy.ue.wroc.pl/uploads/pliki/procesy/wyklady/ZPRnowosielskiWYKLAD .pdf (dostęp: 15.11.2016r.).

[14] Piątkowski T.: Analiza i modelowanie procesu sortowania strumienia małogabarytowych ładunków jednostkowych, Rozprawa nr 139, Uniwersytet Technologiczno-Przyrodniczy im. Jana i Jędrzeja Śniadeckich w Bydgoszczy, Bydgoszcz, 2010.

[15] PN-EN ISO 9000:2006: Systemy zarządzania jakością - podstawy i terminologia, PKN, Warszawa, 2006.

[16] PN-ISO 31000:2010: Zarządzanie ryzykiem - techniki oceny ryzyka, PKN, Warszawa, 2010.

[17] PN-72/M-78000: Transport - określenia podstawowe i podział, Polski Komitet Normalizacji i Miar, Warszawa, 1972.

[18] Pyza D.: Wybrane aspekty modelowania obsługi transportowej w podsystemach dystrybucji, Prace Naukowe Politechniki Warszawskiej, z. 70. Transport, 2009, 139-149.

[19] Salling K.B.: A New Approach to Feasibility Risk Assessment within Transport Infrastructure Appraisal, Procedia - Social and Behavioral Sciences, 2013, 74, $468-477$.

[20] Stajniak M., Foltyński M., Hajdul M., Krupa A.: Transport i spedycja. Podręcznik do kształcenia w zawodzie technik logistyk. ILiM, Biblioteka Logistyka, Poznań, 2007. 
[21] Stephan K., Kelly M., Mcclure R., Seubsman S. , Yiengprugsawan V., Bain Ch., Sleigh A.: The Thai Cohort Study Team Distribution of transport injury and related risk behaviours in a large national cohort of Thai adults, Accident Analysis and Prevention, 2011, 43,1062-1067.

[22] Su D., Guo Z., Li Z., Zhou Y.: Operation risk model and monitoring-warning system of expressway tunnels, Transportation Research Procedia, 2016, 14, $1315-1324$.

[23] Szczepański M.: Ubezpieczenia w logistyce, Wydawnictwo Politechniki Poznańskiej, Poznań, 2011.

[24] Tubis A., Werbińska-Wojciechowska S.: Issues on vulnerability of passenger transportation system, Journal of KONBiN, 2016, nr. 1, 183-192.

[25] Twaróg J.: Logistyczne wskaźniki oceny transport w przedsiębiorstwie produkcyjnym, Logistyka, nr 2/2004, 27-30.

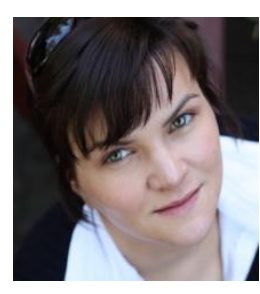

Dr Agnieszka Tubis, Politechnika Wrocławska, Wydziat Mechaniczny, Katedra Eksploatacji Systemów Logistycznych, Systemów Transportowych $i$ Układów Hydraulicznych. Rozprawa doktorska dotyczyta wspótpracy producentów i sieci handlowych $w$ obszarze planowania, prognozowania $i$ uzupetniania zapasów wg koncepcji CPFR. Obecne zainteresowania zwiazane sa $z$ koncepcja controllingu procesowego implementowanego $w$ obszarze zarzadzania eksploatacja pojazdów, zarzadzaniem ryzykiem $w$ przedsiębiorstwach transportowych oraz systemami doradczymi wspierajacymi procesy decyzyjne kadry menedżerskiej $w$ przedsiębiorstwach transportowych (Udziat 50\%).

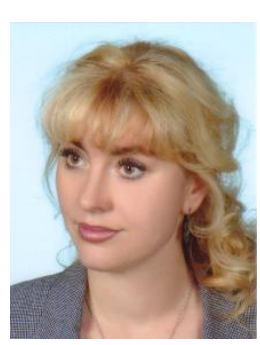

Dr inż. Sylwia Werbińska-Wojciechowska, Politechnika Wroctawska, Wydziat Mechaniczny, Katedra Eksploatacji Systemów Logistycznych, Systemów Transportowych i Układów Hydraulicznych; Rozprawa doktorska obejmowata problematyke modelowania wsparcia logistycznego procesów eksploatacji systemów technicznych; obecnie zainteresowania zwiazane sa $z$ zagadnieniami modelowania strategii utrzymania systemów technicznych $z$ wykorzystaniem koncepcji opóźnień czasowych, modelowania $i$ oceny funkcjonowania systemów transportowych oraz problemów oceny odporności na zagrożenia tańcuchów dostaw (Udział 50\%). 